\title{
Metabolism of Terallethrin in Rats
}

\author{
Kazumasa Minara, Hideo Ohkawa and Junshi Miyamoto \\ Research Department, Pesticide Division, Sumitomo Chemical Co., Ltd., \\ Takarazuka, Hyogo 665, Japan
}

(Received November 29, 1980)

\begin{abstract}
In single oral or subcutaneous administration of ${ }^{14} \mathrm{C}$-terallethrin labeled at the COgroup of the acid moiety to male and female Sprague-Dawley rats at the dose of $5 \mathrm{mg} / \mathrm{kg}$, ${ }^{14} \mathrm{C}$ was rapidly absorbed, and distributed mainly into intestines, liver and kidney. Thereafter, the ${ }^{14} \mathrm{C}$ was rapidly excreted into the urine and feces. During the 7 days following administration, 49 to $62 \%$ of the dosed ${ }^{14} \mathrm{C}$ was found in the urine, 38 to $50 \%$ was in the feces, and totally 97 to $100 \%$ was recovered in the excreta. ${ }^{14} \mathrm{C}$ Residue levels in 23 (female) to 24 (male) tissues were less than $0.09 \mu \mathrm{g}$ terallethrin equivalents/g tissue. Whole-body autoradiography also showed that ${ }^{14} \mathrm{C}$ tissue residues were very low in the rat body. Tlc analysis showed that more than 18 metabolites were present in the urine and feces. One fifth to $0.3 \%$ of the dose of the parent compound was found in the feces. Major metabolites resulted from oxidation of one the gem-dimethyl group attached to the cyclopropane ring and cleavage of the carboxyl ester linkage. Ester metabolites hydroxylated at the 2-methyl and 3-allyl groups of the allethronyl moiety were also found. Hydroxylation at the gem-dimethyl and 3-allyl groups was dominant in male rats, whereas carboxylic acid formation from the gem-dimethyl group was dominant in female rats. No qualitative and quantitative differences in the metabolites were found between oral and subcutaneous administrations.
\end{abstract}

\section{INTRODUCTION}

Terallethrin, $d l-3$-allyl-2-methyl-4-oxo2-cyclopentenyl 2,2,3,3-tetramethylcyclopropane-1-carboxylate, exhibits quick knockdown activity and repellency against many sanitary insects. ${ }^{1)}$ This insecticide is now under development as a mosquito control agent. The acute toxicity of this compound is low in mammals, oral and subcutaneous $\mathrm{LD}_{50}$ values for male rats being 224 and $212 \mathrm{mg} / \mathrm{kg}$, respectively. ${ }^{2}$ This report deals with metabolism of ${ }^{14} \mathrm{C}$ terallethrin in oral or subcutaneous administration to male and female rats.

\section{MATERIALS AND METHODS}

\section{Chemicals}

${ }^{14} \mathrm{C}$-Terallethrin labeled at the CO-group of the acid moiety was prepared by Yoshitake et $a .^{3)}$ of the Institute for Biological Science, Sumitomo Chemical Co., Ltd. The specific activity was $36.8 \mathrm{mCi} / \mathrm{mmol}$ and the radiochemical purity as determined by radio-thin layer chromatography using benzene/acetone
$(10 / 1, v / v)$ and hexane/ethyl ether $(7 / 3, v / v)$ as solvent systems was more than $99 \%$. Terallethrin and tetramethylcyclopropanecarboxylic acid (TMPA) were synthesized in our laboratory. ${ }^{1)} \quad \beta$-Glucuronidase from bovine liver was purchased from Sigma Chemical Co., St. Louis, USA.

\section{Analysis}

For thin-layer chromatography $(t l c)$, precoated silica gel chromatoplates (silica gel 60 $\mathrm{F}_{254}, 0.25 \mathrm{~mm}$ thickness, E. Merck, Darmstadt, Germany) were used. Tlc solvent systems used and $R f$ values for terallethrin and its metabolites are listed in Table 1. Radioactive regions on the developed $t l c$ plates were detected by autoradiography using X-ray films (SB-5, Eastman Kodak Co., New York, USA), and unlabeled reference compounds were visualized under ultraviolet light irradiation. Radioactivity in excreta and silica gel regions scraped from $t l c$ plates was quantitated using a liquid scintillation spectrometer (Packard Tri-Carb 3385, Chicago, USA) 


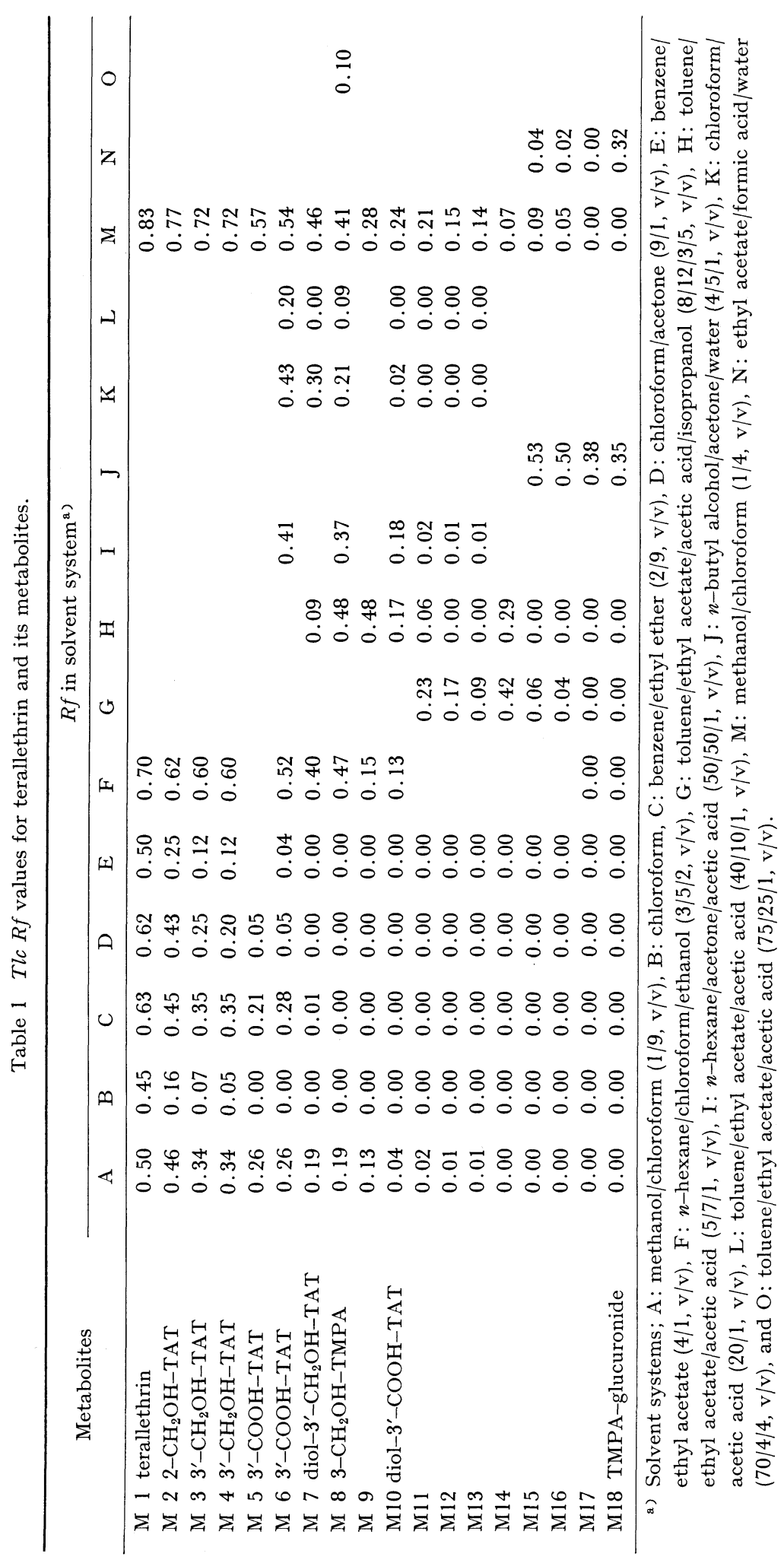


with automatic external standard, as reported previously. ${ }^{4)}$ Aliquots $(0.2 \mathrm{~g})$ of tissues and feces were combusted completely with a sample oxidizer (Packard Tri-Carb 306, Chicago, USA) before liquid scintillation counting (lsc). Produced ${ }^{14} \mathrm{CO}_{2}$ was trapped with a $15: 9$ mixture of ${ }^{14} \mathrm{CO}_{2}$-counting cocktail (OXIPREP ${ }^{\mathrm{TM}-2}$, NEN, Boston, USA) and ${ }^{14} \mathrm{CO}_{2}-$ absorber (OXISORB ${ }^{\mathrm{TM}}-\mathrm{CO}_{2}$, NEN, Boston, USA). In this case, counting efficiency and background levels were more than $73 \%$ and 45 to $55 \mathrm{cpm}$, respectively.

The structure of metabolites was confirmed by nuclear magnetic resonance spectrometry (NMR, Hitachi R-40B or JEOL-JNM-FX100) and/or mass spectrometry [EI-MS, Shimadzu LKB-9000 or Finnigan 4000 at $70 \mathrm{eV}$; CI-MS (methane), Shimadzu LKB$9000 \mathrm{~B}$ at $250^{\circ} \mathrm{C}$; FD-MS, JEOL-JMS01-SG2 at $10 \mathrm{~mA}$ to $20 \mathrm{~mA}$ ].

\section{Treatment of Animals}

Six-week old Sprague-Dawley rats weighing 170 to $180 \mathrm{~g}$ (male) and 130 to $140 \mathrm{~g}$ (female) were supplied by Nihon Dobutsu Co., Osaka, Japan. Rats were placed in polycarbonate cages in an air-conditioned room with the temperature kept at $25 \pm 2^{\circ} \mathrm{C}$, allowed to adjust to the environment for 1 week before administration, and supplied with diet (CE-2, Clea Japan, Inc., Osaka, Japan) and water ad libitum. Male and female rats were administered orally or subcutaneously at the rate of a single dose of $5 \mathrm{mg} / \mathrm{kg}$ of ${ }^{14} \mathrm{C}$-terallethrin suspended in 10\% Tween 80 (Wako Pure Chemical Industries, Ltd., Osaka, Japan). The treated rats were housed individually in metabolism cages (Metabolica CO-2 ${ }^{\circledR}$, Sugiyamagen Iriki Co., Ltd., Tokyo, Japan) to separately collect urine, feces and expired air. During the sampling period, urine and feces were kept at 0 to $5^{\circ} \mathrm{C}$ to prevent metabolites from further alteration. At 7 days after administration, the treated rats were sacrificed. Then tissues were dissected out, homogenized in an equal volume of $0.9 \% \mathrm{NaCl}$, and subjected to combustion analysis for determination of ${ }^{14} \mathrm{C}$ residue levels.

Whole-body autoradiography of male and female rats was conducted as reported previously. ${ }^{5)}$ At various time intervals after oral or subcutaneous administration of ${ }^{14} \mathrm{C}$-terallethrin at the rate of $5 \mathrm{mg} / \mathrm{kg}$. The treated rats were frozen at $-60^{\circ} \mathrm{C}$ and then $20 \mu \mathrm{m}$ left lateral and median plane sections were prepared using a cryomicrotome (LKB2250, Stockholm, Sweden) at $-15^{\circ} \mathrm{C}$. The sections were freeze-dried overnight and layered on X-ray films (SB-5, E. Kodak) and kept in the dark for 25 days at $5^{\circ} \mathrm{C}$.

\section{Metabolite Characterization}

For analysis of metabolites, 2-day pooled urine was neutralized with $1 \mathrm{~N} \mathrm{HCl}$ solution and extracted 3 times with a 3 -fold volume of $80 \%$ aqueous methanol. Two-day pooled feces were homogenized in a 2-fold volume of distilled water using a Waring blender (Nihon Seiki Co., Tokyo, Japan). The homogenates were neutralized with $1 \mathrm{~N} \mathrm{HCl}$ solution and extracted once with a 4-fold volume of methanol, and then extracted twice with a 4-fold volume of $80 \%$ aqueous methanol. These extracts of urine and feces were each concentrated, and the residues were dissolved in a small volume of $80 \%$ aqueous methanol, and subjected to one-dimensional $t l c$ in solvent systems $\mathrm{C}, \mathrm{G}, \mathrm{J}$ and $\mathrm{M}$.

For identification of metabolites, ${ }^{14} \mathrm{C}$-terallethrin with a specific activity of $1.38 \mathrm{mCi} / \mathrm{g}$ was orally administered to 20 male rats at the rate of $50 \mathrm{mg} / \mathrm{kg}$, and 1-day urine and feces were each collected. Urinary and fecal metabolites were each extracted and isolated according to the procedure shown in Fig. 1. Isolated metabolites and their derivatives were each subjected to NMR and/or MS. A fraction of polar metabolites which was located at the origin of $t l c$ plates developed with solvent system $M$ was subjected to enzymatic hydrolysis. The fraction extracted with $80 \%$ methanol from the gel region was incubated with $\beta$-glucuronidase in $5 \mathrm{ml}$ of $0.1 \mathrm{~m}$ acetate buffer, $\mathrm{pH} 5$, at $37^{\circ} \mathrm{C}$ for $16 \mathrm{hr}$. Then the reaction mixture was subjected to column chromatography on Amberlite XAD-2 resin $(10 \mathrm{ml})$ and eluted with $15 \mathrm{ml}$ of water, followed by $30 \mathrm{ml}$ of methanol. The methanol fraction was concentrated in vacuo and the residue dissolved in a small volume of methanol was subjected to $t l c$. 


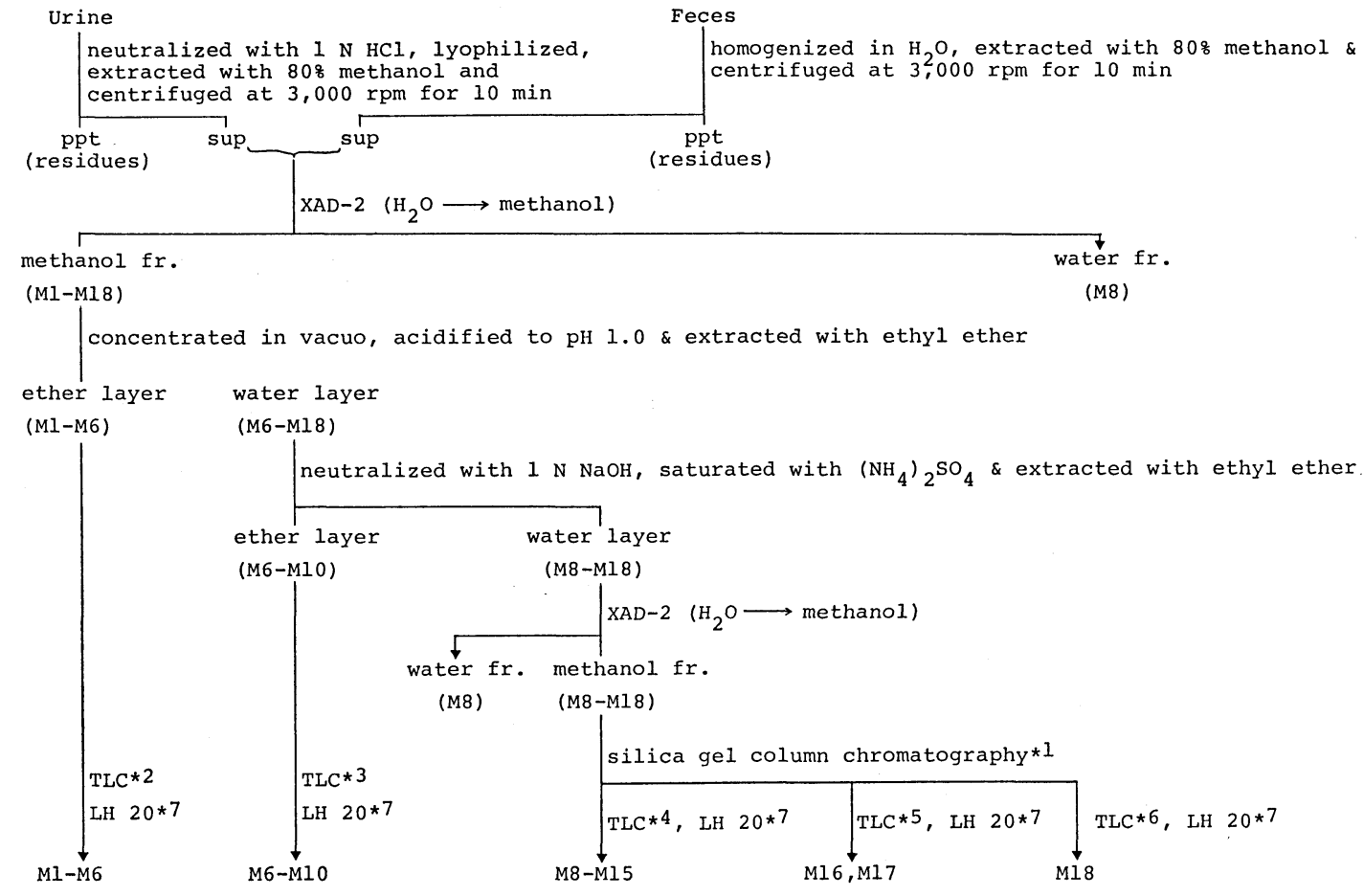

Fig. 1 Isolation of ${ }^{14} C$-terallethrin metabolites in the urine and feces.

*1 solvent systems, methanol/chloroform $(1 / 4, \mathrm{v} / \mathrm{v})$ and methanol.

Tlc solvent systems used: See footnote in Table 1 .

*2 A, B, C, D, E, F, K \& L, ${ }^{* 3}:$ A, C, F, H, K. L \& M, *4: H, G \& M,

*5: J, *6 J \& N.

*7 Sephadex LH 20 column chromatography eluted with methanol.

\section{RESULTS}

\section{Absorption, Distribution and Excretion}

Whole-body autoradiography of both male and female rats orally treated with $5 \mathrm{mg} / \mathrm{kg}$ of ${ }^{14} \mathrm{C}$-terallethrin showed that the radioactivity was localized in digestive organs including stomach, small intestine and large intestine to a large extent, and in the liver and kidney to a lesser extent 1 to $6 \mathrm{hr}$ after treatment. Almost no radioactivity was detected in other tissues. Thereafter, the radioactivity disappeared readily from these organs and was only slightly detected in the body at $24 \mathrm{hr}$ post-treatment, as shown in Fig. 2.

On subcutaneous administration of ${ }^{14} \mathrm{C}-$ terallethrin to male and female rats, the radioactivity was rapidly distributed into liver, intestines and kidney, whereas other tissues contained lesser amounts of it. Once entering into the blood stream, the ${ }^{14} \mathrm{C}$ was distributed more or less similarly to that of oral administration.

When each of the 3 male and female rats were orally or subcutaneously treated with ${ }^{14} \mathrm{C}$-terallethrin at $5 \mathrm{mg} / \mathrm{kg}$, the radioactivity was rapidly excreted mainly into urine and feces, as shown in Table 2. One day after single administration, 85 to $92 \%$ of the oral dose and 74 to $98 \%$ of the subcutaneous dose were recovered in the urine and feces. During the 2 days following both treatments, more than $95 \%$ of the dose was recovered in the urine and feces. The radiocarbon excretion was substantially completed 4 to 7 days after both treatments. Thirtyeight to $50 \%$ and 49 to $62 \%$ of the dose was found in the feces and urine, respectively. The radioactivity excreted in expired air was less than $1 \%$. 

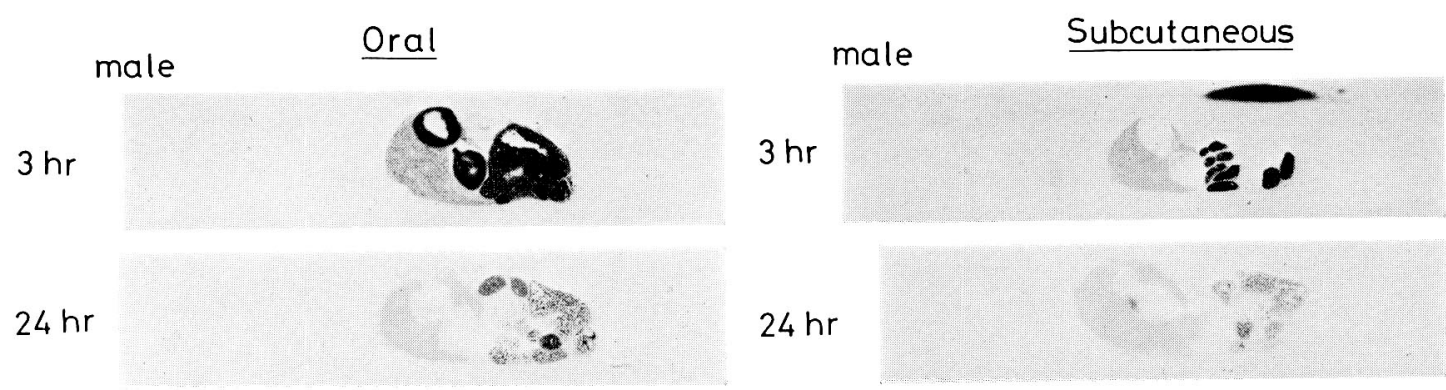

female

female

$3 \mathrm{hr}$

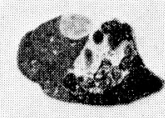

$3 \mathrm{hr}$

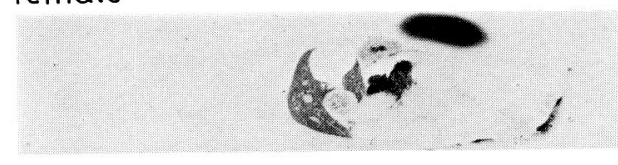

$24 \mathrm{hr}$

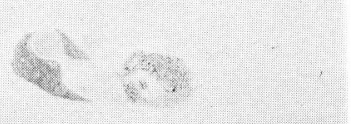

$24 \mathrm{hr}$

Fig. 2 Autoradiograms (left lateral sections) showing distribution of radioactivity in the male and female rat bodies $3 \mathrm{hr}$ and $24 \mathrm{hr}$ after oral or subcutaneous administration of ${ }^{14} \mathrm{C}$-terallethrin at $5 \mathrm{mg} / \mathrm{kg}$.

Table 2 Cumulative excretion of radiocarbon after oral or subcutaneous administration of $5 \mathrm{mg} / \mathrm{kg}$ of ${ }^{14} \mathrm{C}$-terallethrin to 3 male and female rats.

\begin{tabular}{|c|c|c|c|c|c|c|}
\hline \multirow{3}{*}{ Route } & \multirow{3}{*}{$\operatorname{Sex}$} & \multirow{3}{*}{ Excreta } & \multicolumn{4}{|c|}{$\begin{array}{l}\% \text { of the administered radiocarbon } \\
\text { (mean value } \pm \mathrm{SE} \text { ) }\end{array}$} \\
\hline & & & \multicolumn{4}{|c|}{ Day after administration } \\
\hline & & & 1 & 2 & 4 & 7 \\
\hline \multirow[t]{6}{*}{ Oral } & Male & urine & $54.5 \pm 2.3$ & $56.1 \pm 2.0$ & $56.5 \pm 2.0$ & $56.6 \pm 2.0$ \\
\hline & & feces & $37.9 \pm 0.4$ & $39.7 \pm 0.3$ & $40.1 \pm 0.3$ & $40.2 \pm 0.3$ \\
\hline & & total & $92.4 \pm 2.1$ & $95.8 \pm 1.7$ & $96.6 \pm 1.7$ & $96.8 \pm 1.7$ \\
\hline & Female & urine & $56.0 \pm 1.7$ & $59.8 \pm 1.2$ & $61.0 \pm 1.0$ & $61.2 \pm 1.0$ \\
\hline & & feces & $28.8 \pm 2.5$ & $37.8 \pm 5.4$ & $38.7 \pm 5.6$ & $38.9 \pm 5.7$ \\
\hline & & total & $84.8 \pm 2.9$ & $97.6 \pm 4.8$ & $99.7 \pm 5.6$ & $100.1 \pm 5.7$ \\
\hline \multirow[t]{6}{*}{$\mathrm{SC}^{\mathrm{a})}$} & Male & urine & $42.1 \pm 4.8$ & $48.2 \pm 4.8$ & $49.2 \pm 4.3$ & $49.4 \pm 4.7$ \\
\hline & & feces & $35.4 \pm 1.9$ & $47.1 \pm 4.3$ & $49.4 \pm 4.6$ & $49.7 \pm 4.6$ \\
\hline & & total & $77.5 \pm 3.0$ & $95.3 \pm 0.9$ & $98.6 \pm 0.8$ & $99.1 \pm 0.7$ \\
\hline & Female & urine & $53.0 \pm 2.2$ & $59.3 \pm 3.1$ & $61.4 \pm 3.4$ & $61.7 \pm 3.4$ \\
\hline & & feces & $20.7 \pm 6.3$ & $35.9 \pm 3.9$ & $38.0 \pm 3.9$ & $38.4 \pm 3.8$ \\
\hline & & total & $73.7 \pm 4.4$ & $95.2 \pm 0.9$ & $99.4 \pm 1.0$ & $100.1 \pm 1.0$ \\
\hline
\end{tabular}

a) subcutaneous administration.

\section{Tissue Residue}

Table 3 shows ${ }^{14} \mathrm{C}$ tissue residue levels 7 days after oral or subcutaneous treatment of both male and female rats with $5 \mathrm{mg} / \mathrm{kg}{ }^{14} \mathrm{C}_{-}$ terallethrin. In most of the 23 to 24 tissues analyzed, less than $0.05 \mu \mathrm{g}$ terallethrin equivalents/g tissue was found, although 0.07 to $0.09 \mu \mathrm{g}$ terallethrin equivalents/g tissue were found in the liver and kidney of female rats. 
Table $3{ }^{14} \mathrm{C}$ Contents in tissues of 3 male and female rats 7 days after oral or subcutaneous administration of $5 \mathrm{mg} / \mathrm{kg}$ of ${ }^{14} \mathrm{C}$-terallethrin.

\begin{tabular}{|c|c|c|c|c|}
\hline \multirow{3}{*}{ Tissue } & \multicolumn{4}{|c|}{${ }^{14} \mathrm{C}$ Content ( $\mu \mathrm{g}$ terallethrin equivalents/g tissue) } \\
\hline & \multicolumn{2}{|c|}{ Oral } & \multicolumn{2}{|c|}{ Subcutaneous } \\
\hline & Male & Female & Male & Female \\
\hline Blood & 0.01 & 0.01 & 0.02 & 0.02 \\
\hline Heart & 0.01 & 0.02 & 0.01 & 0.02 \\
\hline Kidney & 0.05 & 0.09 & 0.04 & 0.07 \\
\hline Liver & 0.04 & 0.08 & 0.03 & 0.07 \\
\hline Spleen & 0.01 & 0.02 & $<0.01$ & 0.02 \\
\hline Pancreas & 0.01 & 0.02 & $<0.01$ & 0.02 \\
\hline Lung & 0.01 & 0.02 & 0.02 & 0.03 \\
\hline Brain & $<0.01$ & $<0.01$ & $<0.01$ & $<0.01$ \\
\hline Adrenal & 0.01 & 0.03 & 0.01 & 0.03 \\
\hline Muscle & 0.01 & 0.01 & $<0.01$ & 0.02 \\
\hline Sciatic nerve & 0.01 & 0.02 & 0.01 & 0.02 \\
\hline Spinal cord & $<0.01$ & $<0.01$ & $<0.01$ & $<0.01$ \\
\hline Salivary gland & $<0.01$ & 0.02 & $<0.01$ & 0.02 \\
\hline Thyroid gland & 0.01 & 0.01 & 0.02 & 0.03 \\
\hline Thymus & $<0.01$ & 0.02 & $<0.01$ & 0.02 \\
\hline Fat & $<0.01$ & 0.01 & 0.02 & 0.04 \\
\hline Hair and skin & 0.02 & 0.03 & 0.01 & 0.03 \\
\hline Urinary bladder & 0.02 & 0.03 & 0.01 & 0.03 \\
\hline Stomach & $<0.01$ & $<0.01$ & $<0.01$ & $<0.01$ \\
\hline Intestine & $<0.01$ & 0.01 & $<0.01$ & 0.01 \\
\hline Caecum & $<0.01$ & 0.01 & $<0.01$ & 0.02 \\
\hline Testis & $<0.01$ & - & $<0.01$ & - \\
\hline Uterus & - & 0.03 & - & 0.03 \\
\hline Ovary & - & 0.02 & - & 0.02 \\
\hline
\end{tabular}

\section{Metabolite Identification}

As listed in Table 4, more than 18 metabolites were detected in the urine and feces by tlc. Metabolites M1, M2, M3, M4, M13, M15, M16 and M17 were found in the feces, whereas metabolites M5, M9, M12, M14 and M18 were found in the urine. Metabolites M6, M7, M8, M10 and M11 were found both in the urine and feces, although amounts of these metabolites were larger in the urine than in the feces. Significant qualitative and quantitative differences in metabolites were few between oral and subcutaneous administrations.

Metabolite M1 was identified as terallethrin by $t l c$ cochromatography with the authentic standard in solvent systems A, B, C, D, E and $\mathrm{F}$.

The NMR spectrum $(100 \mathrm{MHz})$ of metabolite M2 was as follows: $\delta_{\mathrm{TMS}}^{\mathrm{CDCl}_{3}}: 1.22-1.27$ $\left(12 \mathrm{H}\right.$, a mixture of 2 singletes $2^{\prime}-\mathrm{CH}_{3} \times 2 \&$ $\left.3^{\prime}-\mathrm{CH}_{3} \times 2\right), \quad 1.2-1.4\left(1 \mathrm{H}, \mathrm{C}_{1}-\mathrm{H}\right), 2.43(1 \mathrm{H}$, d d, $\left.J=20 \mathrm{~Hz}, 2.2 \mathrm{~Hz}, \mathrm{C}_{5}-\mathrm{H}_{\mathrm{a}}\right), 2.87$ ( $1 \mathrm{H}, \mathrm{d} \mathrm{d}$, $J=20 \mathrm{~Hz}, 7 \mathrm{~Hz}, \mathrm{C}_{5}-\mathrm{H}_{\mathrm{b}}$ ), $3.03[2 \mathrm{H}, \mathrm{d}$ (broad), $\left.J=6.5 \mathrm{~Hz}, 3-\mathrm{C}_{(1)}-\mathrm{H}_{2}\right], 4.20(1 \mathrm{H}, \mathrm{d}, J=16 \mathrm{~Hz}$, $\left.2-\mathrm{CH}_{\mathrm{a}}\right), 4.56\left(1 \mathrm{H}, \mathrm{d}, \mathrm{J}=16 \mathrm{~Hz}, 2-\mathrm{CH}_{\mathrm{b}}\right), 5.02$ $\left[2 \mathrm{H}, \quad \mathrm{d}\right.$ (broad), $\left.J=14 \mathrm{~Hz}, \quad 3-\mathrm{C}_{(3)}-\mathrm{H}_{2}\right]$ and 5.6-6.0 (2 H, m, 3- $\left.\mathrm{C}_{(2)}-\mathrm{H}, \mathrm{C}_{1}-\mathrm{H}\right)$. These data indicated the presence of 2-hydroxymethyl group in the alcohol moiety. Treatment of the metabolite with acetic anhydride in the presence of pyridine gave one major product with $R f$ values of 0.26 and 0.72 in solvent systems B and E, respectively. The CI (methane)-MS spectra of the product showed fragments at m/e $335(\mathrm{M}+1)$ and $275(\mathrm{M}-$ $\left.\mathrm{OCOCH}_{3}\right)$, indicating acetylation of the 2hydroxymethyl group of M2. The NMR spectra of the acetylated M2 showed the presence of an acetyl proton signal at $\delta_{\mathrm{TMS}}^{\mathrm{CDCl}_{3}}$ : 2.09. Based on these data, metabolite M2 was identified as $d l-3$-allyl-2-hydroxymethyl4-oxo-2-cyclopentenyl 2', 2',3',3'-tetramethyl 
Table 4 Relative amounts of metabolites excreted into the urine and feces during $48 \mathrm{hr}$ after oral or subcutaneous administration of $5 \mathrm{mg} / \mathrm{kg}$ of ${ }^{14} \mathrm{C}$-terallethrin to male and female rats.

\begin{tabular}{|c|c|c|c|c|c|c|c|c|}
\hline \multirow{4}{*}{ Metabolite } & \multicolumn{8}{|c|}{ Amount ( $\%$ of the excreted radiocarbon) } \\
\hline & \multicolumn{4}{|c|}{ Oral } & \multicolumn{4}{|c|}{ Subcutaneous } \\
\hline & \multicolumn{2}{|c|}{ Male } & \multicolumn{2}{|c|}{ Female } & \multicolumn{2}{|c|}{ Male } & \multicolumn{2}{|c|}{ Female } \\
\hline & Urine & Feces & Urine & Feces & Urine & Feces & Urine & Feces \\
\hline M 1 & nd & 0.3 & nd & 0.3 & nd & 0.2 & nd & 0.2 \\
\hline M 2 & nd & 0.7 & nd & 0.5 & nd & 0.7 & nd & 0.4 \\
\hline M 3 & nd & 0.8 & nd & 0.2 & nd & 2.4 & nd & 1.4 \\
\hline M 4 & nd & 1.1 & nd & 0.5 & nd & 1.7 & nd & 0.5 \\
\hline M 5 & 0.6 & nd & 2.0 & nd & nd & nd & 2.8 & nd \\
\hline M 6 & 8.3 & 3.5 & 18.0 & 3.1 & 4.6 & 5.0 & 15.2 & 1.5 \\
\hline M 7 & 4.3 & 1.5 & 1.7 & 0.7 & 2.9 & 2.2 & 1.2 & 0.3 \\
\hline M 8 & 15.9 & 6.0 & 8.6 & 3.0 & 12.8 & 6.4 & 9.6 & 2.6 \\
\hline M 9 & 2.0 & nd & 1.3 & nd & 1.8 & nd & 1.9 & nd \\
\hline M10 & 3.5 & 2.3 & 2.1 & 2.0 & 4.0 & 3.1 & 2.5 & 1.3 \\
\hline M11 & 1.8 & nd & 2.6 & 2.0 & 1.1 & 1.5 & 2.6 & 1.6 \\
\hline M12 & 2.6 & nd & 2.2 & nd & 3.2 & nd & 1.2 & nd \\
\hline M13 & nd & 2.0 & nd & 1.7 & nd & 1.9 & nd & 0.9 \\
\hline M14 & 3.7 & nd & 4.2 & nd & 3.7 & nd & 5.3 & nd \\
\hline M15 & nd & 7.4 & nd & 5.8 & nd & 6.3 & nd & 4.1 \\
\hline M16 & nd & 3.0 & nd & 5.8 & nd & nd & nd & 4.5 \\
\hline M17 & nd & 7.6 & nd & 10.3 & nd & 9.0 & nd & 11.7 \\
\hline M18 & 12.9 & nd & 16.3 & nd & 13.9 & nd & 18.3 & nd \\
\hline Others $\left.^{a}\right)$ & 3.0 & nd & 2.3 & nd & 2.6 & nd & 1.7 & nd \\
\hline Residues $^{\text {b) }}$ & nd & 5.2 & nd & 2.8 & nd & 9.0 & nd & 6.7 \\
\hline Total & 58.6 & 41.4 & 61.3 & 38.7 & 50.6 & 49.4 & 62.3 & 37.7 \\
\hline
\end{tabular}

a) methanol soluble, b) methanol insoluble ${ }^{14} \mathrm{C}$.

nd: less than $0.1 \%$ of the dose.

A.

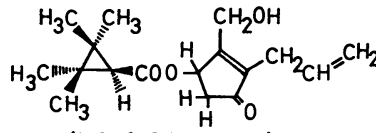

(M2, 2- $\mathrm{CH}_{2} \mathrm{OH}-\mathrm{TAT}$ )

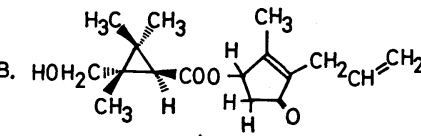

( $\mathrm{M} 3$ and $\mathrm{M} 4,3^{\prime}-\mathrm{CH}_{2} \mathrm{OH}-\mathrm{TAT}$ )

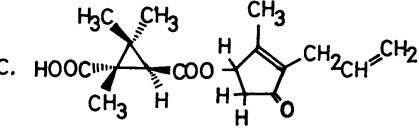

(M5 and M6, $3^{\prime}-\mathrm{COOH}-\mathrm{TAT}$ )

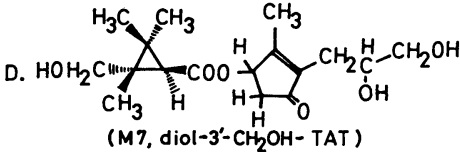

E. $\mathrm{HOH}_{2}$

(M8; 3- $\left.\mathrm{CH}_{2} \mathrm{OH}-\mathrm{TMPA}\right)$

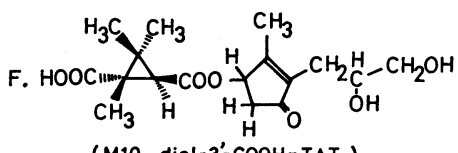

(M10, diol-3'- $\mathrm{COOH}-\mathrm{TAT}$ )

Fig. 3 Structures for metabolites M2, M3, M4, M5, M6, M7, M8 and M10. 
cyclopropane-1'-carboxylate $\left(2-\mathrm{CH}_{2} \mathrm{OH}-\mathrm{TAT}\right)$, as shown in Fig. 3A.

The NMR spectrum $(90 \mathrm{MHz})$ of metabolite M3 was as follows: $\delta_{\mathrm{TMS}}^{\mathrm{CDCl}_{3}}: 1.23(1 \mathrm{H}, \mathrm{s}$, $\left.\mathrm{C}_{1^{\prime}}-\mathrm{H}\right), 1.30\left(6 \mathrm{H}, \mathrm{s}, 2^{\prime}-\mathrm{CH}_{3} \times 2\right), 1.40(3 \mathrm{H}, \mathrm{s}$, $\left.3^{\prime}-\mathrm{CH}_{3}\right), 2.03\left(3 \mathrm{H}, \mathrm{s}, 2-\mathrm{CH}_{3}\right), 2.25(1 \mathrm{H}, \mathrm{d} \mathrm{d}$, $\left.J=20 \mathrm{~Hz}, 2.2 \mathrm{~Hz}, \mathrm{C}_{5}-\mathrm{H}_{\mathrm{a}}\right), 2.90(1 \mathrm{H}, \mathrm{d} \mathrm{d}$, $\left.J=20 \mathrm{~Hz}, 7 \mathrm{~Hz}, \mathrm{C}_{5}-\mathrm{H}_{\mathrm{b}}\right), 3.01(2 \mathrm{H}, \mathrm{d}, J=6.5$ $\left.\mathrm{Hz}, 3-\mathrm{C}_{(1)}-\mathrm{H}_{2}\right), \quad 3.5-3.8\left(2 \mathrm{H}, \mathrm{m}, 3^{\prime}-\mathrm{CH}_{2} \mathrm{O}\right)$, $5.06\left[2 \mathrm{H}, \mathrm{d}\right.$ (broad), $\left.J=14 \mathrm{~Hz}, 3-\mathrm{C}_{(3)}-\mathrm{H}_{2}\right]$ and 5.6-6.0 (2 H, m, 3- $\left.\mathrm{C}_{(2)}-\mathrm{H}, \mathrm{C}_{1}-\mathrm{H}\right)$. The EI-MS spectra of metabolite M3 showed the largest fragment at $m / e 293(\mathrm{M}+1)$. These data indicated that a methyl group of the acid moiety was hydroxylated. Reflux of the metabolite in $1 \mathrm{~N} \mathrm{NaOH}$ solution for $1 \mathrm{hr}$ gave a product with $R f$ value of 0.10 in solvent system $O$. The NMR spectrum $(90 \mathrm{MHz})$ of the product was as follows: $\delta_{\mathrm{TMS}}^{\mathrm{CDCl}_{3}}: 1.3-1.4$ $\left(10 \mathrm{H}\right.$, a mixture of 3 singletes, $\mathrm{C}_{1}-\mathrm{H}, 3-\mathrm{CH}_{3} \times$ 2, $\left.2-\mathrm{CH}_{3}\right) 3.55\left(1 \mathrm{H}, \mathrm{d}, J=12 \mathrm{~Hz}, 3-\mathrm{CH}_{\mathrm{a}} \mathrm{O}\right)$ and $3.74\left(1 \mathrm{H}, \mathrm{d}, J=12 \mathrm{~Hz}, 3-\mathrm{CH}_{\mathrm{b}} \mathrm{O}\right)$. The $\mathrm{CI}$ (methane)-MS spectrum of the product showed the largest fragment at $m / e \quad 141$ $\left(\mathrm{M}+1-\mathrm{H}_{2} \mathrm{O}\right)$. The FD-MS spectrum of the product showed the fragments at m/e 357 $\left(2 \mathrm{M}+{ }^{41} \mathrm{~K}\right), 355\left(2 \mathrm{M}+{ }^{39} \mathrm{~K}\right), 339(2 \mathrm{M}+\mathrm{Na})$, $317(2 \mathrm{M}+1), 197(\mathrm{M}+\mathrm{K}), 181(\mathrm{M}+\mathrm{Na}), 159$ $(\mathrm{M}+1)$ and $141\left(\mathrm{M}+1-\mathrm{H}_{2} \mathrm{O}\right)$. From these data, the product was presumed to be 2,2,3-trimethyl-trans-3-hydroxymethyl cyclopropanecarboxylic acid (3- $\left.\mathrm{CH}_{2} \mathrm{OH}-\mathrm{TMPA}\right)$. The $t l c$ $R f$ value $(0.10)$ of the alkaline degradation product in solvent $\mathrm{O}$ coincided well with that of $3-\mathrm{CH}_{2} \mathrm{OH}-\mathrm{TMPA}$, as described by Crawford. ${ }^{6)}$ 2,2,3-Trimethyl-cis-3-hydroxymethyl cyclopropanecarboxylic acid was easily lactonized under acidic conditions and on $t l c$ plates developed with acidic solvent systems, ${ }^{7)}$ but this product did not undergo lactonization under the same conditions. Therefore, M3 was identified as $d l-3-$ allyl-2-methyl-4-oxo-2cyclopentenyl $\quad 2^{\prime}, 2^{\prime}, 3^{\prime}-$ trimethyl-trans $-3^{\prime}-$ hydroxymethyl cyclopropane-1'-carboxylate $\left(3^{\prime}-\mathrm{CH}_{2} \mathrm{OH}-\mathrm{TAT}\right)$, as shown in Fig. 3B.

The NMR spectrum $(90 \mathrm{MHz})$ of metabolite M4 was follows: $\delta_{\mathrm{TMS}}^{\mathrm{CDCl}_{3}}: 1.21\left(1 \mathrm{H}, \mathrm{s}, \mathrm{C}_{1}-\mathrm{H}\right)$, $1.31\left(6 \mathrm{H}, \mathrm{s}, 2^{\prime}-\mathrm{CH}_{3} \times 2\right), 1.37\left(3 \mathrm{H}, \mathrm{s}, 3^{\prime}-\mathrm{CH}_{3}\right)$, $2.03\left(3 \mathrm{H}, \mathrm{s}, 2-\mathrm{CH}_{3}\right), 2.24(1 \mathrm{H}, \mathrm{d} d, J=20 \mathrm{~Hz}$, $\left.2.2 \mathrm{~Hz}, \mathrm{C}_{5}-\mathrm{H}_{\mathrm{a}}\right), 2.88(1 \mathrm{H}, \mathrm{d} \mathrm{d}, J=20 \mathrm{~Hz}, 7$ $\left.\mathrm{Hz}, \mathrm{C}_{5}-\mathrm{H}_{\mathrm{b}}\right), 3.01\left(2 \mathrm{H}, \mathrm{d}, J=6.5 \mathrm{~Hz}, 3-\mathrm{C}_{(1)}-\right.$
$\left.\mathrm{H}_{2}\right)$, 3.4-3.9 (2 H, m, 3'- $\left.\mathrm{CH}_{2} \mathrm{O}\right), 5.04[2 \mathrm{H}, \mathrm{d}$ (broad), $\left.J=14 \mathrm{~Hz}, \quad 3-\mathrm{C}_{(3)}-\mathrm{H}_{2}\right]$ and $5.5-6.0$ $\left(2 \mathrm{H}, \mathrm{m}, 3-\mathrm{C}_{(2)}-\mathrm{H}, \mathrm{C}_{1}-\mathrm{H}\right)$. The EI-MS spectrum of metabolite M4 showed the largest fragment at $m / e 293(\mathrm{M}+1)$. These data indicated that a methyl group of the acid moiety was hydroxylated, similar to the case of metabolite M3. The metabolite was refluxed in $1 \mathrm{~N} \mathrm{NaOH}$ solution for $1 \mathrm{hr}$ to give a product which was identified as $3-\mathrm{CH}_{2} \mathrm{OH}-\mathrm{TMPA}$ by tlc cochromatography with the authentic standard in solvent system $O$. So it seemed that M4 had the same plane structure as M3. However, as shown in Table 1, M3 and M4 are different in $t l c R f$ values in solvent systems $B$ and D. Since hydroxylation at the $3^{\prime}-$ methyl group of the acid moiety introduced an asymmetric center and the $\mathrm{C}_{1}$-carbon of the allethronyl moiety is also asymmetric, metabolites M3 and M4 appear to be diasteromeric to each other.

The NMR spectrum $(100 \mathrm{MHz})$ of metabolite M5 was as follows: $\delta_{\mathrm{TMS}}^{\mathrm{CDCl}_{3}}: 1.1-1.5$ $\left(10 \mathrm{H}\right.$, a mixture of 4 singletes, $\mathrm{C}_{1}-\mathrm{H}, 2^{\prime}-$ $\left.\mathrm{CH}_{3} \times 2 \& 3^{\prime}-\mathrm{CH}_{3}\right), 2.04\left(3 \mathrm{H}, \mathrm{s}, 2-\mathrm{CH}_{3}\right), 2.22$ $\left(1 \mathrm{H}, \mathrm{d} \mathrm{d}, J=20 \mathrm{~Hz}, 2.2 \mathrm{~Hz}, \mathrm{C}_{5}-\mathrm{H}_{\mathrm{a}}\right), 2.68$ $\left(1 \mathrm{H}, \mathrm{d} \mathrm{d}, J=20 \mathrm{~Hz}, 7 \mathrm{~Hz}, \mathrm{C}_{5}-\mathrm{H}_{\mathrm{b}}\right), 2.98(2 \mathrm{H}$, d, $\left.J=6.5 \mathrm{~Hz}, 3-\mathrm{C}_{(1)}-\mathrm{H}_{2}\right), 5.02[2 \mathrm{H}$, d(broad), $\left.J=14 \mathrm{~Hz}, \quad 3-\mathrm{C}_{(3)}-\mathrm{H}_{2}\right]$ and $5.5-5.8(2 \mathrm{H}, \mathrm{m}$, $\left.3-\mathrm{C}_{(2)}-\mathrm{H}, \mathrm{C}_{1}-\mathrm{H}\right)$. These data indicated that a methyl group of the acid moiety was oxidized to a carboxyl group. Treatment of the metabolite with diazomethane gave one major product with $R f$ values of $0.74,0.56,0.54$ and 0.36 in solvent systems $\mathrm{A}, \mathrm{C}, \mathrm{D}$ and $\mathrm{E}$, respectively, which gave a methoxy signal at $\delta_{\mathrm{TMS}}^{\mathrm{CDCl}_{3}}: 3.78$ in the NMR spectrum $(100 \mathrm{MHz})$. M5 in $1 \mathrm{~N} \mathrm{NaOH}$ solution was refluxed for $1 \mathrm{hr}$ to give a product with $R f$ values of 0.53 , 0.18 and 0.44 in solvent systems $\mathrm{H}, \mathrm{M}$ and $\mathrm{O}$, respectively. The product was treated with diazomethane to give one major product with $R f$ values of $0.60,0.60$ and 0.54 in solvent systems $\mathrm{C}, \mathrm{D}$ and $\mathrm{E}$, respectively, which gave the fragments at $m / e 200(\mathrm{M}), 185\left(\mathrm{M}-\mathrm{CH}_{3}\right)$, $169\left(\mathrm{M}-\mathrm{OCH}_{3}\right)$ and $141\left(\mathrm{M}-\mathrm{COOCH}_{3}\right)$ in EI-MS spectrum. Therefore, the methylated product was confirmed to be dimethyl ester of 2,2,3 trimethyl-trans-3-carboxyl cyclopropanecarboxylic acid (3-COOH-TMPA). Based on these data, as shown in Fig. 3C, M5 was 
identified as $d l-3-$ allyl-2-methyl-4-oxo-2cyclopentenyl $\quad 2^{\prime}, 2^{\prime}, 3^{\prime}$-trimethyl-trans-3'carboxyl cyclopropane- $1^{\prime}-$ carboxylate $\quad\left(3^{\prime}-\right.$ COOH-TAT).

The NMR spectrum $(90 \mathrm{MHz})$ of metabolite M6 was as follows: $\delta_{\mathrm{TMS}}^{\mathrm{CDCl}_{3}}: 1.2-1.5(1 \mathrm{H}$, $\left.\mathrm{C}_{1}{ }^{\prime}-\mathrm{H}\right), 1.22\left(3 \mathrm{H}, \mathrm{s}, 2^{\prime}-\mathrm{CH}_{3}\right), 1.31(3 \mathrm{H}, \mathrm{s}$, $\left.2^{\prime}-\mathrm{CH}_{3}\right), 1.47\left(3 \mathrm{H}, \mathrm{s}, 3^{\prime}-\mathrm{CH}_{3}\right), 2.06(3 \mathrm{H}, \mathrm{s}$, $\left.2-\mathrm{CH}_{3}\right), 2.20\left(1 \mathrm{H}, \mathrm{d} \mathrm{d}, J=20 \mathrm{~Hz}, 2.2 \mathrm{~Hz}, \mathrm{C}_{5}-\right.$ $\left.\mathrm{H}_{\mathrm{a}}\right), 2.88\left(1 \mathrm{H}, \mathrm{d} \mathrm{d}, J=20 \mathrm{~Hz}, 7 \mathrm{~Hz}, \mathrm{C}_{5}-\mathrm{H}_{\mathrm{b}}\right)$, $3.00\left(2 \mathrm{H}, \mathrm{d}, J=6.5 \mathrm{~Hz}, 3-\mathrm{C}_{(1)}-\mathrm{H}_{2}\right), 5.03[2 \mathrm{H}$, $\mathrm{d}$ (broad), $\left.J=14 \mathrm{~Hz}, 3-\mathrm{C}_{(3)}-\mathrm{H}_{2}\right]$ and 5.6-6.0 $\left(2 \mathrm{H}, \mathrm{m}, 3-\mathrm{C}_{(2)}-\mathrm{H}, \mathrm{C}_{1}-\mathrm{H}\right)$. The metabolite was hydrolyzed under the same conditions as M5 to give 3-COOH-TMPA. The metabolite was treated with diazomethane to give one major product with $R f$ values of $0.74,0.62,0.59$ and 0.46 in solvent systems $\mathrm{A}, \mathrm{C}, \mathrm{D}$ and $\mathrm{E}$, respectively. The NMR spectrum $(100 \mathrm{MHz})$ of the methylated M6 showed a methoxy signal at $\delta_{\mathrm{TMS}}^{\mathrm{CDCl}_{3}}: 3.70$. Based on these data, M6 was also identified as $3^{\prime}-\mathrm{COOH}-\mathrm{TAT}$. However, it appears that M5 and M6 were diastereomeric each other because of the presence of two asymmetric carbon atoms $\mathrm{C}_{1}$ and $\mathrm{C}_{3^{\prime}}$ in the molecule of 3 '-COOH-TAT.

The NMR spectrum $(90 \mathrm{MHz})$ of metabclite M7 was as follows: $\delta_{\mathrm{TMS}}^{\mathrm{CDCl}_{3}}: 1.3-1.4(9 \mathrm{H}$, a mixture of 3 singletes, $\left.2^{\prime}-\mathrm{CH}_{3} \times 2 \& 3^{\prime}-\mathrm{CH}_{3}\right)$, 1.0-1.4 (1 H, C $1-\mathrm{H}), 2.07\left(3 \mathrm{H}, \mathrm{s}, 2-\mathrm{CH}_{3}\right), 2.29$ $\left(1 \mathrm{H}, \mathrm{d} \mathrm{d}, J=20 \mathrm{~Hz}, 2.2 \mathrm{~Hz}, \mathrm{C}_{5}-\mathrm{H}_{\mathrm{a}}\right), 2.47(2 \mathrm{H}$, d, $\left.J=6.0 \mathrm{~Hz}, 3-\mathrm{C}_{(1)}-\mathrm{H}_{2}\right), 2.67[2 \mathrm{H}, \mathrm{s}$ (broad), $3-\mathrm{C}_{(2)}-\mathrm{OH}, 3-\mathrm{C}_{(3)}-\mathrm{OH}$ ], $2.92(1 \mathrm{H}, \mathrm{d}$ d, $J=20$ $\left.\mathrm{Hz}, 6.5 \mathrm{~Hz}, \mathrm{C}_{5}-\mathrm{H}_{\mathrm{b}}\right), 3.53\left(2 \mathrm{H}, \mathrm{s}, 3^{\prime}-\mathrm{CH}_{2} \mathrm{O}\right), 3.4$ $3.8\left[1 \mathrm{H}, \mathrm{s}\right.$ (broad), $\left.3^{\prime}-\mathrm{CR}-\mathrm{OH}\right], 3.66(2 \mathrm{H}, \mathrm{d}, J=$ $\left.6.5 \mathrm{~Hz}, 3-\mathrm{C}_{(3)}-\mathrm{H}_{2} \mathrm{O}\right), 3.80\left(1 \mathrm{H}, \mathrm{m}, 3-\mathrm{C}_{(2)}-\mathrm{H}\right)$ and 5.6-5.8 $\left(1 \mathrm{H}, \mathrm{m}, \mathrm{C}_{1}-\mathrm{H}\right)$. The hydroxy proton signals at $\delta_{\mathrm{TMS}}^{\mathrm{CDCl}_{3}}: 2.67$ and one hydroxy signal at $\delta_{\mathrm{TMS}}^{\mathrm{CDCl}_{3}}: 3.4-3.8$ in the NMR spectrum $(100 \mathrm{MHz})$ of $\mathrm{M} 7$ were removed when shaken with $\mathrm{D}_{2} \mathrm{O}$. Compared with the NMR spectrum of terallethrin, one methyl proten signal of the acid moiety and 3 olefinic proton signals corresponding to the $-\mathrm{CH}=\mathrm{CH}_{2}$ group in the allethronyl moiety were lacking. The EI-MS spectrum of metabolite M7 showed the largest fragment at $m / e 308\left(\mathrm{M}-\mathrm{H}_{2} \mathrm{O}\right)$. These data indicated that 3-allyl group of the allethronyl moiety and one methyl group of the acid moiety were hydroxylated. Hydrolysis of M7 in $0.1 \mathrm{~N} \mathrm{NaOH}$ (refluxed for $1 \mathrm{hr}$ ) gave 3 -
$\mathrm{CH}_{2} \mathrm{OH}$-TMPA. Metabolite M7 was treated with acetic anhydride in the presence of pyridine to give a product with $R f$ values of $0.71,0.02$ and 0.41 in solvent systems A, B and $\mathrm{D}$, respectively. The NMR spectrum of the acetylated M7 showed the presence of three acetyl proton signals at $\delta_{\mathrm{TMS}}^{\mathrm{CDCl}} \mathrm{Cl}_{3}: 2.08$. The EI-MS spectrum of the acetylated M7 showed the fragments at $m / e \quad 452$ (M), 393 $\left(\mathrm{M}-\mathrm{CH}_{3} \mathrm{COOH}\right), 353\left(\mathrm{M}-\mathrm{CH}_{3} \mathrm{CO}-\mathrm{CH}_{3} \mathrm{COO}\right)$ and $352\left(\mathrm{M}-\mathrm{CH}_{3} \mathrm{CO}-\mathrm{CH}_{3} \mathrm{COOH}\right)$. From those data, M7 was identified as $d l-3-(2,3-$ diol-propyl)-2methyl-4-oxo-2-cyclopentenyl $2^{\prime}, 2^{\prime}, 3^{\prime}$-trimethyl-trans $-3^{\prime}$ - hydroxymethyl cyclopropane-1'-carboxylate (diol- $3^{\prime}-\mathrm{CH}_{2} \mathrm{OH}-\mathrm{TAT}$ ), as shown in Fig. 3D.

The NMR spectrum $(90 \mathrm{MHz})$ and $t l c R f$ values in solvent systems $A, H, I, K$ and $O$ of metabolite M8 coincided with those of 3$\mathrm{CH}_{2} \mathrm{OH}-\mathrm{TMPA}$ (shown in Fig. 3E).

The NMR spectrum $(90 \mathrm{MHz})$ of metabolite M10 was as follows: $\delta_{\mathrm{TMS}}^{\mathrm{CD}_{3} \mathrm{OD}}: 0.9-1.6(1 \mathrm{H}$, $\left.\mathrm{C}_{1}-\mathrm{H}\right), 1.2-1.5(9 \mathrm{H}$, a mixture of 3 singletes, $\left.2^{\prime}-\mathrm{CH}_{3} \times 2 \& 3^{\prime}-\mathrm{CH}_{3}\right), 2.1\left(3 \mathrm{H}, \mathrm{s}, 2-\mathrm{CH}_{3}\right), 2.21$ $\left(1 \mathrm{H}, \mathrm{d} \mathrm{d}, J=20 \mathrm{~Hz}, 2.2 \mathrm{~Hz}, \mathrm{C}_{5}-\mathrm{H}_{\mathrm{a}}\right), 2.41$ $\left(2 \mathrm{H}, \mathrm{d}, J=6.5 \mathrm{~Hz}, 3-\mathrm{C}_{(1)}-\mathrm{H}_{2}\right), 2.60(1 \mathrm{H}, \mathrm{d} d$, $\left.J=20 \mathrm{~Hz}, 6.5 \mathrm{~Hz}, \mathrm{C}_{5}-\mathrm{H}_{\mathrm{b}}\right), 3.5(2 \mathrm{H}, \mathrm{d}, J=$ $\left.6.5 \mathrm{~Hz}, 3-\mathrm{C}_{(3)}-\mathrm{H}_{2} \mathrm{O}\right), 3.7-3.9\left(1 \mathrm{H}, \mathrm{m}, 3-\mathrm{C}_{(2)}-\mathrm{H}\right)$ and 5.7-5.8 $\left(1 \mathrm{H}, \mathrm{m}, \mathrm{C}_{1}-\mathrm{H}\right)$. These data indicated oxidation of one methyl group to carboxyl group and hydroxylation of the 3allyl group in the allethronyl moiety. Hydrolysis of metabolite $\mathrm{M} 10$ in $1 \mathrm{~N} \mathrm{NaOH}$ (refluxed for $1 \mathrm{hr}$ ) gave 3-COOH-TMPA, which was identical on $t l c$ in solvent systems $\mathrm{H}, \mathrm{M}$ and $\mathrm{O}$ with the hydrolyzed metabolite of M6. Treatment of metabolite M10 with diazomethane, followed by treatment with acetic anhydride in the pyridine gave one major product with $R f$ values of $0.74,0.39$ and 0.17 in solvent systems $\mathrm{A}, \mathrm{C}$ and $\mathrm{E}$, respectively, which showed in the NMR spectrum $(100 \mathrm{MHz})$ two acetyl proton signals at $\delta_{\mathrm{TMS}}^{\mathrm{CDCl}_{3}}: 2.08$ and one methoxy proton signal at $\delta_{\mathrm{TMS}}^{\mathrm{CDCl}_{3}}: 3.74$. Based on these data, M10 was identified as $d l-3-(2,3-$ diolpropyl)-2-methyl-4-oxo-2-cyclopentenyl-2', $2^{\prime}, 3^{\prime}$-trimethyl-trans-3'-carboxyl cyclopropane-1'-carboxylate (diol- $3^{\prime}-\mathrm{COOH}-\mathrm{TAT}$ ), as shown in Fig. 3F.

On treatment with $\beta$-glucuronidase, metabolite M18 released TMPA as aglycone. So M18 
was presumed to be $\beta$-glucuronide conjugate of TMPA, TMPA-glucuronide.

The identified urinary and fecal ${ }^{14} \mathrm{C}$-metabolites corresponded to $60-70 \%$ of the dosed ${ }^{14} \mathrm{C}$. Of these, metabolites retaining the carboxyl ester linkage accounted for more than 30\% of the dose; the major ones were $2-\mathrm{CH}_{2} \mathrm{OH}-$, $3^{\prime}-\mathrm{CH}_{2} \mathrm{OH}-, 3^{\prime}-\mathrm{COOH}-$, diol- $-3^{\prime}-\mathrm{CH}_{2} \mathrm{OH}-$ and diol-3'-COOH-TAT. Terallethrin was less than $0.3 \%$ of the dose. The metabolites resulting from cleavage of the carboxyl ester linkage accounted for 30 to $35 \%$ of the dose; the major metabolites were TMPA-glucuronide and $3-\mathrm{CH}_{2} \mathrm{OH}-\mathrm{TMPA}$. The metabolites resulting from oxidation of the gem-dimethyl group of the acid moiety were approximately $40 \%$ of the dose. A trace amount of the hydroxylated metabolites at the 3-methyl or 2-allyl groups was also found. There was a sex difference in relative amounts of ${ }^{14} \mathrm{C}$-metabolites in the excreta. With male rats, hydroxylation of the gem-dimethyl group of the acid moiety and the 3-allyl group of the allethronyl moiety was predominant, whereas the carboxyl derivatives of the gem-dimethyl group of the acid moiety were predominant with female rats. However, no qualitative and quantitative differences in the metabolites were found between oral and subcutaneous administrations.

\section{DISCUSSION}

In oral or subcutaneous administration to both male and female rats of $5 \mathrm{mg} / \mathrm{kg}$ of ${ }^{14} \mathrm{C}$ terallethrin, the radiocarbon was mainly distributed into intestines, liver and kidney, and then excreted completely into the urine and feces. After 7 days post-treatment, the ${ }^{14} \mathrm{C}$ tissue residues were very low. $T l c$ analysis of the urine and feces showed that more than 18 metabolites were present. The parent compound was found in the feces to the extent of only 0.2 to $0.3 \%$ of the dose. Major metabolites resulted from cleavage of the carboxyl ester linkage, and oxidation at a methyl group of the acid moiety. No qualitative and quantitative differences in the metabolites were found between oral and subcutaneous treatments. However, there was a difference in relative amounts of metabolites between male and female rats. Oxidation of the gem-dimethyl group of the acid moiety to the hydroxymethyl group and the 3-allyl group of the allethronyl moiety to $3-\mathrm{CH}_{2} \mathrm{CHOHCH}_{2} \mathrm{OH}$ was more predominant with male rats than with female rats, whereas oxidation of the hydroxymethyl group to the carboxyl group was reversed. Figure 4 shows proposed metabolic pathways for terallethrin in rats on the basis of the identified metabolites.

Most of the synthetic pyrethroids are known to be metabolized in rat via cleavage of the

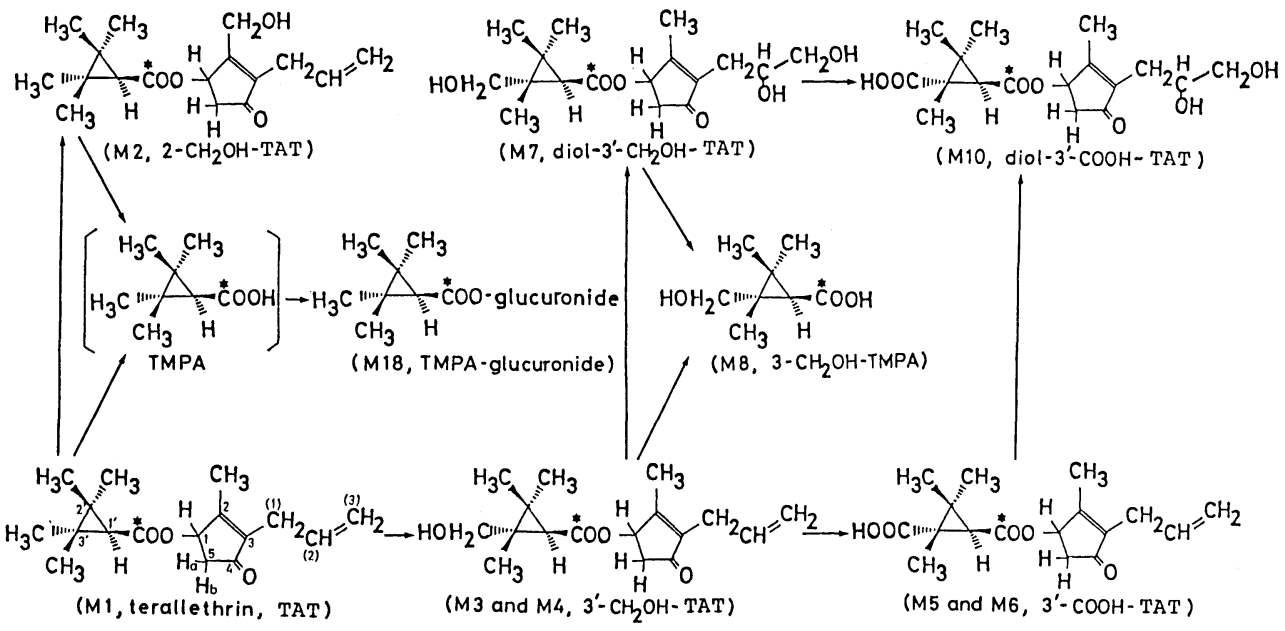

Fig. 4 Proposed metabolic pathways for ${ }^{14} C$-terallethrin in rats.

* ${ }^{14} \mathrm{C}$ labeling position. 
carboxyl ester linkage and oxidations at various positions of both alcohol and acid moieties. Hydrolysis products from primary alcohol esters of trans-acids such as trans-phenothrin and trans-permethrin accounted for 91 to $96 \%$ of the dose in the rat, whereas those from the cis-acid esters and secondary alcohol esters such as fenpropanate, fenvalerate, trans-cypermethrin and decamethrin accounted for 75 to $88 \%$ of the dose. ${ }^{7-10)}$ The cis-acid esters and secondary alcohol esters are shown to be more slowly hydrolyzed than the trans-acid esters by carboxyesterase(s) of rat liver. On the other hand, the hydrolysis products from terallethrin accounted for 27 to $33 \%$ of the dose in the rat. These results seem to be comparable with those of pyrethrin I and II and allethrin. ${ }^{11}$ It seems that the esters of allethrolone are more or less hydrolyzed in the rat as compared with those derived from 3 -phenoxybenzyl alcohol and $\alpha$-cyano-3phenoxybenzyl alcohol. ${ }^{12,13}$ ) That is, allethrolone esters including terallethrin appear to be mainly metabolized oxidatively in rats.

Terallethrin was oxidized at one of the methyl groups of the tetramethylcyclopropanecarboxylic acid moiety in the transorientation to the carboxyl group in rats, and cis-hydroxylation metabolites which would easily lactonize were not found. Similar trans-hydroxylation was found with fenpropanate in rats. ${ }^{6)}$

Oxidation at the 3-allyl and 2-methyl groups of the allethronyl moiety also occurred with terallethrin. With allethrin metabolism in rats, ${ }^{11,14)}$ oxidation of the 3-allyl group to $3-\mathrm{CHOHCH}=\mathrm{CH}_{2}$ and $3-\mathrm{CH}_{2} \mathrm{CHOHCH}_{2} \mathrm{OH}$ was found, but oxidation of the 2-methyl group did not occur, although the latter oxidation was known with allethrone metabolism in Aspergillus niger. ${ }^{15)}$

\section{ACKNOWLEDGEMENTS}

The authors wish to express their thanks to Miss I. Furukawa for technical assistance. Deep appreciation is extended to Mr. K. Nakai of the Section of Material Science, Research Department, Sumitomo Chemical Co., Ltd., for precision FD-MS spectral analysis.

\section{REFERENCES}

1) M. Matsui \& T. Kitahara: Agric. Biol. Chem. 31, 1143 (1967)

2) H. Koda, T. Suzuki, T. Kadota \& J. Miyamoto: unpublished observations (1979)

3) T. Yoshitake \& I. Nakatsuka: unpublished

4) K. Mihara, H. Ohkawa \& J. Miyamoto: J. Pesticide Sci. 6, 65 (1981)

5) K. Mihara \& J. Miyamoto: Agric. Biol. Chem. 28, 1913 (1974)

6) M. J. Crawford \& D. H. Hutson: Pestic. Sci. 8, 579 (1977)

7) J. E. Casida, L. C. Gaughan \& L. O. Ruzo: "Advances in Pesticide Sciences," ed. by $\mathrm{H}$. Geissbühler, Part 2, Pergamon Press, Oxford, p. 182,1979

8) T. Suzuki, N. Ohno \& J. Miyamoto: J. Pesticide Sci. 1, 151 (1976)

9) M. Elliott, N. F. Janes, D. A. Pulman, L. C. Gaughan, T. Unai \& J. E. Casida: J. Agric. Food Chem. 24, 270 (1976)

10) L. C. Gaughan, T. Unai \& J. E. Casida: J. Agric. Food Chem. 25, 9 (1977)

11) M. Elliott, N. F. Janes, E. C. Kimmel \& J. E. Casida: J. Agric. Food Chem. 20, 300 (1972)

12) C. O. Abernathy, K. Ueda, J. L. Engel, L. C. Gaughan \& J. E. Casida: Pestic. Biochem. Physiol. 3, 300 (1973)

13) D. M. Soderlund \& J. E. Casida: Pestic. Biochem. Physiol. 7, 319 (1977)

14) J. E. Casida, E. C. Kimmel, M. Elliott \& N. F. Janes: Nature 230, 326 (1971)

15) R. A. LeMahieu, B. Tabenkin, J. Berger \& R. W. Kierstead: J. Org. Chem. 35, 1987 (1970)

\section{要約}

\section{テラレスリンのラットにおける代謝}

三原一優, 大川秀郎, 宮本純之

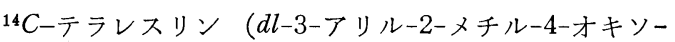
2-シクロペソテニル $2,2,3,3$-テトラメチルシクロプロ パソ-1ーカルボキシレート, 酸側 $\mathrm{CO}$ 基標識) を $5 \mathrm{mg} / \mathrm{kg}$ の割合で SD 系雌雄ラットに 1 回経口もしくは皮下投与 すると, いずれの場合も ${ }^{14} \mathrm{C}$ は速やかにラット体内に吸 収されて, 腸, 肝臓, 腎藏などの臓器に分布した。 その 後 ${ }^{14} \mathrm{C}$ は速やかに体外に排泄され，投与 $0 \sim 2$ 日間の尿 に $48.2 \sim 59.8 \%$ ，䔬に $35.9 \sim 47.1 \%$ ，合計 $95.2 \sim$ $97.6 \%$ ，投与 $0 \sim 7$ 日間には合計 $96.8 \sim 100.1 \%$ が回 収された. 主要組織 (雄 24 , 雌 23 種) 中の ${ }^{14} \mathrm{C}$ 残存 量はいずれも低く, 投与. 7 日後で $0.09 \mu \mathrm{g}$ テラレスリン 相当量 $/ g$ 組織 以下であった，尿および瞥中に排泄され 
た ${ }^{14} \mathrm{C}$ 代謝物は少なくとも 18 個以上からなり，親化合 物は翼中に $0.2 \sim 0.3 \%$ 認められるのみであった。おも な代謝物は酸側の gem-ジメチル基の酸化およびカルボ キシルエステル結合の開裂にともなう生成物であった。 そのほかにフレスロロン側の 2 -メチル基のヒドロキシ
メチル体，3-アリル基の水酸化体が認められた. 雄ラッ トでは雌ラットに比べて，gem-ジメチル基拉よび 3-フ リル基の水酸化体が多く，それに対して gem-ジメチル 基のカルボキシル基への酸化体は少なかった。 